\title{
SOME SUGGESTIONS ON HOW TO IDENTIFY AND CLASSIFY BEHAVIORAL PROCESSES IN ENGLISH AND VIETNAMESE
}

\author{
Nguyen Thi Tu Trinh*,1, Phan Van $\mathrm{Hoa}^{2}$, Tran Huu Phuc ${ }^{3}$ \\ ${ }^{\prime}$ Department of English, College of Transport II, \\ 28 Ngo Xuan Thu, Lien Chieu, Danang, Vietnam \\ ${ }^{2}$ Department of International Education, University of Danang, \\ 41 Le Duan, Hai Chau, Danang, Vietnam \\ ${ }^{3}$ University of Foreign Language Studies, University of Danang, \\ 131 Luong Nhu Hoc, Khue Trung, Cam Le, Danang, Vietnam
}

Received 03 June 2016

Revised 06 May 2017; Accepted 19 May 2017

\begin{abstract}
Unlike material processes which possess rather distinctive features both semantically and lexicogrammatically, behavioral processes do not possess features that characterize themselves as a distinctive grammatical category. Due to their semantic ambiguity, they often cause a lot of troubles for identification and classification. Great efforts have been made to shed light on this matter in both English and Vietnamese (Halliday, 1994; Halliday \& Matthiessen, 2004; Eggins, 1994; Martin et. al., 1997; Hoang Van Van, 2012), but there still remain problems that need more clarification. In this paper, we will make an attempt to explore in some depth the causes of the troubles and offer some suggestions on how those troubles should be shot. The data for study is 200 behavioural clauses in English and Vietnamese collected from short stories and novels. The analysis is based on Halliday (1994)'s systemic functional grammar framework. The study suggests that in order to be able to identify and classify appropriately a behavioral process (verb), it must be placed in relation to other components of the clause, and both semantic (meaning) and lexicogrammatical (structure) criteria should be taken into consideration.
\end{abstract}

Keywords: functional grammar, troubleshooting, behavioral clause

\section{Introduction}

Halliday and Matthiessen (2004) state that "The transitivity system construes the world of experience into a manageable set of PROCESS TYPES. Each process type provides its own model or schema for construing a particular domain of experiment as a figure of particular kind". Functional grammar theory categorizes experience in terms of process types which are realized by verbal groups. Particularly, this structure is

\footnotetext{
* Corresponding author. Tel.: 84-1656592033

Email: trinhtoeic@gmail.com
}

fundamentally determined by the constraints imposed by the main lexical verb, and it is this element that is primarily analyzed in order to identify a particular process. In addition, the method of analyzing clauses for their process type relies on two criteria: semantic and syntactic. The semantic and syntactic criteria that distinguish between processes are detailed in Halliday's work (1994). Nevertheless, there is a conflict in employing these two criteria to analyze and categorize behavioral clauses. Halliday (1994) points out: "Behavioral processes are the least distinct of all the six process types because 
they have no clearly defined characteristics of their own; rather, they are partly like the material and partly like the mental". In this paper, we address and interpret the source of troubleshooting in analyzing and categorizing these ambiguous behavioral clauses in English and Vietnamese. We suppose here that the problems face the analyst may be due to the conflict between the semantic and syntactic streams of information. We examine carefully selected data in order to figure out why the problem occurs when analyzing and categorizing these ambiguous behavioral clauses in English and Vietnamese. Furthermore, we discuss whether semantic criteria will always be the favored interpretation over syntactic structure. It is hoped that these findings will help understand more why indeterminacy occurs as well as set a more standard form of behavioral clauses analysis.

\subsection{Theoretical background}

According to Halliday (1994: xiv) "A Functional Grammar is one that construes all the units of a language-its clauses, phrases and so-on as organic configurations of functions." Thus, his aim is to develop a grammar system as instrument for people's communication, for social purposes. Halliday states that there are three types of meaning within grammatical structures namely: Experiential meaning, Interpersonal meaning and Textual meaning. Among them, experiential meaning has to do with the ways language represents our experience of the world and the inner world of our thoughts and feelings. In other words, we have turned our experience of actions, happenings, feelings, beliefs, situations, states, behaviors and so on, into meaning and into wording. It construes the world into a manageable set of Process types and of Participants. Process refers to a semantic verb (doing, happening, feeling, sensing, saying, behaving, and existing) and anything that it expresses like event, relation, physical, mental or emotional state when sorted in the semantic system of the clause is classified into material, relational, mental, verbal, behavioral, and existential processes and Participants are labeled such as Actor, Goal; Senser, Phenomenon; Carrier, Behaver and so on.

\subsection{Some previous studies}

Many researchers are keen on analyzing functional grammar and the transitivity system in literary discourses. Martin et al. (1997) offer a wide range of grammatical analyses provided by Halliday. It helps students to understand Halliday's ideas and to apply them in the analysis of English texts. Bloor and Bloor (1995) present a short account to the analysis of English for those starting out with functional grammar. Bloor and Bloor introduce this particular model to the readers to analyze real samples of English. Eggins (1994) introduces the principles and techniques of the functional approach to language in order that readers may begin to analyze and explain how meanings are made in everyday linguistic interactions.

O'Donnell et al. (2009) conducted an online survey where they asked practitioners to select the process type of 32 clauses, most of the instances offering some difficulties. They explore three kinds of clines, namely Behavioral-verbal cline, Behavioral-mental cline, Behavioralmaterial cline. There is a gradual shift of coding from behavioral to the other category. Besides, they point out the confusion deriving from the choices of conceptual or syntactic criteria. The root of different choices among coders is the path they follow in analyzing behavioral clauses. One is based on conceptual criteria 
and the other relies on syntactic criteria.

Gwilliams and Fontaine (2015) devote their effort to finding out some indeterminacy in process type classification. They conduct a survey on experienced SFL users for their classification of 20 clauses. They find out that there is inconsistency of analysis and the main area of disagreement between analysts was the selection of Material vs. Verbal processes.

Hoang Van Van (2012) adopts Halliday's functional grammar's framework to describe the experiential grammar of the Vietnamese clause. He recognized six process types in Vietnamese: material, behavioural, mental, verbal, relational, and existential. And in his description of behavioral clauses in Vietnamese, Hoang Van Van (Ibid.) notes some troubles (indeterminacy) that need to be shot. He suggests classifying ambiguous behavioural clauses in Vietnamese into para-material (clauses that lie on the borderline between material and behavioural processes), para-verbal (clauses that lie on the borderline between behavioural and verbal processes), and paramental (clauses that lie on the borderline between behavioural and mental processes). Although Hoang Van Van does not go into detail to show how the troubles should be shot, his description, however, has thrown some light on how solving the problem of ambiguity, providing some basis for making a comparison between behavioural clauses in English and Vietnamese using systemic functional grammar as the theoretical framework.

\section{Method}

\subsection{Data collection}

200 behavioral clauses in 16 short stories and novels in English and
Vietnamese in the $19^{\text {th }}$ and $20^{\text {th }}$ centuries are collected. These clauses are considered behavioral clauses based on Halliday and Matthiessen (2004), Martin et al. (1997), Bloor and Bloor (1995), Eggins (1994) and Hoang Van Van (2012). The selection of behavioral clauses starts with behavioral process type. We make a decision to carry out the research in stories and novels but not in other genres since stories and novels reflect the reality through different lens of writers and behavioral processes are commonly used in narrative texts. Therefore, they are rich in examples of behavioral clauses and we can explore more problematic cases of behavioral clauses via verbal channel.

\subsection{Data analysis}

A language is a complex system composed of multiple levels. In this paper, the collected data are examined at simple clause level in the light of functional grammar elaborated by Halliday (1994) since functional analysis is concerned with the aspect of grammar which confines to clauses, examples of the whole texts don't seem necessary. In addition, this study follows functional-structural approach and employs processes (verbs) as the core of the clauses and whenever there is a conflict in analyzing and categorizing process types due to the confusion of semantic and syntactic choice, we are in favor of semantic. It is obvious that "function" is what language is doing for the speaker and 'Structure" is how language is organized by the speaker and formed by the language and it is impossible to have one without the other. However, in light of functional grammar, we give priority to function or meaning. After identifying and collecting all the clauses, we analyze and categorize these clauses in English and Vietnamese in terms of unambiguous and 
ambiguous cases. Then we interpret the similar and distinctive characteristics of unambiguous and ambiguous cases in terms of the sources of troubleshooting in English and Vietnamese and offer some solutions to the ambiguous cases.

\section{Results and discussion}

\subsection{Unambiguous cases}

According to Halliday and Matthiessen (2004), Behavioral processes are processes of psychological and physiological process, like breathing, coughing, smiling, dreaming, chatting, watching, etc. This helps us sort out verbs that can be labeled as behavioral processes.

Consider the following two clauses:

(1) The five miners sighed, bowed, and, trembling with the struggle.

(2) She sobbed violently on his shoulder, whilst he held her still, waiting.

These two clauses belong to Behavioral processes that they both describe human's behaviors. In addition, each clause has $a$ Behaver which performs or does an action.

There are also two sub-types of behavioral process in Vietnamese namely psychological and physiological behavioral Processes.

\section{Psychological behavioral processes}

Let us consider further examples of psychological behavioral process in Vietnamese:

(3) Chí Phèo bỗng nằm dài không nhúc nhích rên khe khẽ như gần chết. [9]

(4) Lão ngẩn mặt ra một chút, rồi bỗng nhiên thở dài.

(5) Cụ bá cuời nhạt.

In examples (3), (4), (5), the behavioral clauses are constructed employing the behavioral processes in the form of "intransitive verbs" "rên" ("moan"), "thở dài" ("sigh") and "cười nhạt" ("sneer"). In particular, "rên" ("moan”), "thở dài” ("sigh") and "cười nhạt" ("sneer") are the most common psychological signals of man.

Physiological behavioral processes

Mồm hắn ngáp ngáp

Behaver Process: Physiological behavioral

[9]

(7)

\begin{tabular}{lll}
\hline Hắn & bỗng nhiên & rùng mình. \\
Behaver & Circ: Manner & Process: \\
& & $\begin{array}{l}\text { Physiological- } \\
\text { behavioral }\end{array}$ \\
\hline
\end{tabular}

[9]

The verb "ngáp ngáp" and "rùng minh" in (6) and (7) are clearly labeled as physiological behavioral processes when we consider the semantic features of the processes "ngáp ngáp" and "rùng minh" themselves. Their subjects "Mồm hắn" and "Hắn" would be portrayed as Behaver. A number of physiological behavioral processes are found in our selected data; for examples:

(8) Thỉnh thoảng y lại hít mạnh vào một cái và đưa tay lên quệt mép.

(9) Lão nuốt nước dãi, rít đến "sị̂" một cái qua những kẽ răng thưa, hơi há mồm ra, khoe những chiếc răng khểnh, như suốt đời chưa bao giờ ăn cả.

The above discussed behavioral clauses don't lie on the borderline between material, mental and verbal. So they have clearly defined characteristics of their own. We don't have difficulties analyzing them and therefore, they are considered as umambiguous or distinctive cases.

\subsection{Ambiguous cases}

Webster (2014: 4) offers a useful discussion of indeterminacy in language and how SFL has developed to deal with it. As he explains, "very different perspective 
is reflected in descriptions of language as a social-semiotic system, which focus on its role in defining human experience, and enacting the social relations essential to our shared sense of humanity". This perspective allows us to accept "irregularity and asymmetry in language" as inherent to the language system. In this paper, we are interested in the causes of troubleshooting in analyzing behavioral processes. Fawcett (2010) states that one source of difficulties stems from the ambiguous verbs. When verbs have an ambiguous form and can be analyzed by a number of different processes depending upon the textual environment. For example, the verb got can realize (1) a Relational process by assigning an attribute: Ivy got worried, or a possession Ivy got a new climbing rope; (2) Material as in the directional Ivy got to the shop in time or the influential Ivy got him to eat it. Interestingly, in examining and analyzing selected behavioral clauses, we also find out the inconsistency arising from process itself in different context. An interpretation for shooting the troubles in analyzing behavioral clauses will be discussed at process and clause level.

\subsubsection{At process level}

A simple clause may have either one or more than one lexical verb. In this part, we just focus on the challenges in analyzing single verb clauses. The difficulty in analyzing these clauses is that it will sometimes be unclear what functions are being represented by the speaker. Although some verbs are easier to identify and label, there are some ambiguous ones to analyze and classify due to their wide semantic distribution. In other words, the issue is that a single verb may meet the criteria of more than one category. Let us consider the following examples.

It is obvious that they are single lexical
(9)

\begin{tabular}{|c|c|c|}
\hline $\begin{array}{c}\text { Her } \\
\text { hands }\end{array}$ & trembled & $\begin{array}{c}\text { slightly at her } \\
\text { work }\end{array}$ \\
\hline Behaver & $\begin{array}{c}\text { Process: } \\
\text { behavioral }\end{array}$ & $\begin{array}{c}\text { Circumstance: } \\
\text { manner }\end{array}$ \\
\hline
\end{tabular}

[1]

(10)

\begin{tabular}{|c|c|}
\hline Daisy and Gatsby & Danced \\
\hline Behaver & $\begin{array}{c}\text { Process: Material- } \\
\text { behavioral }\end{array}$ \\
\hline
\end{tabular}

verb clauses but the verb "tremble" in (9) is clearly labeled as behavioral process while the verb danced in (10) is unclearly identified as it is on the borderline of material processes and behavioral processes. This kind of verb can be labeled as Materialbehavioral processes (cf. Hoang Van Van (2012)'s notion of para-material process). This is where we encounter our first troubleshooting in working out with the specific process type.

We also find a conscious difficulty in analyzing and classifying the following example.

(11) Colonel Dent and Mr. Eshton argue on politics.

When we just consider the semantic features of the process "argue" itself. It belongs to Verbal processes. Its subject "Colonel Dent and Mr. Eshton" would be assigned the role of Sayer and the adjunct "on politics" would be labeled as Verbiage. Seen from the point of view of semantics, however, it seems to be a misinterpretation. It is suggested that "argue" be Verbal - behavioral processes, and accordingly "Colonel Dent and Mr. Eshton" be Behaver (cf. Hoang Van Van (2012)'s notion of para-verbal process). So with this view, it is safe to say that Verbal - behavioral processes share the characteristics of verbal and behavioral processes, they also represent process of saying, telling, and stating. It should be analyzed as follows. 


\begin{tabular}{|c|c|c|}
\hline Colonel Dent and Mr. Eshton & argue & on politics \\
\hline Behaver & Process: Verbal-behavioral & Participant (Verbiage) \\
\hline
\end{tabular}

It is very difficult for us to find out the clear border between behavioral processes and mental processes because there are complexities that we have not explored yet. We focus on discussing some differences between them in this part. Halliday (1994), Halliday and Matthiessen (2004) note that one significant difference between them is in their unmarked present tense. In mental processes, the unmarked present tense is the simple present but in behavioral processes, the unmarked present tense is the present continuous. Last but not least, semantically mental processes encode meanings of thinking and feeling while behavioral processes are processes of behaving or performing an action. The blending Mental-behavioral processes inherit some characteristics of these two processes, as in the following examples:
The three subtypes of behavioral processes, namely Material-behavioral, Verbal - behavioral and Mental - behavioral processes, are carefully analyzed above. These three subtypes are also found in Vietnamese. The next section covers the main issues of troubleshooting in analyzing Behavioral clauses at clause level in English. At this level, we take the semantics of clause as central to our analysis and categorization.

\subsubsection{At clause level}

\subsubsection{A clause with "dumb" processs}

\section{Relational or behavioral clauses}

In this section, these processes are called "dumb" since the meanings of these processes don't make any contributions to the meaning of the clause. In other words, they are significant at syntactical ground but

\begin{tabular}{|c|c|c|}
\hline She & laughed & with thrilling scorn \\
\hline Behaver & Process: mental-behavioral & Circumstance \\
\hline
\end{tabular}

In Vietnamese, we also encounter the same troubles that should be shot in analyzing and classifying Vietnamese behavioral clauses as in the following examples.

(13)

\begin{tabular}{|l|l|l|l|}
\hline $\begin{array}{l}\text { Xuân } \\
\text { Xuan }\end{array}$ & $\begin{array}{c}\text { nhồm nhoàm } \\
\text { smearing }\end{array}$ & $\begin{array}{c}\text { nhai } \\
\text { chew }\end{array}$ & $\begin{array}{l}\text { mía } \\
\text { sugar cane }\end{array}$ \\
\hline Behaver & Circumstance: Manner & Process: Material-behavioral & Participant \\
\hline
\end{tabular}

'Xuan noisily chews sugar cane'

(14)

\begin{tabular}{|l|l|c|}
\hline $\begin{array}{l}\text { Hắn } \\
\mathrm{He}\end{array}$ & $\begin{array}{l}\text { chưi } \\
\text { insult }\end{array}$ & $\begin{array}{c}\text { ngay tất cả làng Vũ Đại } \\
\text { all village Vu Dai }\end{array}$ \\
\hline Behaver & Process: Verbal-behavioral & Participant (Receiver) \\
\hline
\end{tabular}

'He insults all people in Vu Dai village' 
disagreement between syntactic and semantic choice. That causes indeterminacy in clause analysis based on experiential meaning. Let us consider the following examples.

(15a) She was still sort of crying.

(15b) She was crying a bit.

It is clear that participants, a significant aspect of transitivity, are the same entity but they are different in analyzing based on experiential meaning. "She" in (15a) is labeled as 'Carrier' while "She" in (15b) is labeled as 'Behaver'. Besides, the nature of the process types is completely different. In comparing the Relational clause (15a) and the Behavioral clause (15b) above, a number of distinctions can be found, that is, they are built on distinctive syntactic grounds despite their similarity in meaning. In addition, while they are both clause types construing human behavior 'crying', they have different participants and processes. Relational clause (15a) and Behavioral clause (15b) can be analyzed as follows. behavioral clauses? And do we base semantic or syntactic criteria? It is obvious that (15a) is a kind of relational clause if we base ourselves on syntactic grounds (structural approach) but it is behavioral one if we analyze it based on semantic ground (functional approach). This example is a typical case of distinction that can be made upon syntactic differences with clause structure. As far as we know, structure of language is significant and in many cases, it is impossible to separate function from structure. As we stated above, we follow functional-structural approach in favor of the idea that meaning base is the most important. In this light of view, relational clause (15a) is considered as behavioral clause in my study.

In Vietnamese, these cases are not found in our selected data. We haven't seen any ambiguity between Relational and Behavioral interpretation of the clause but we find the evidence to show that there

(15a)

\begin{tabular}{|c|c|c|}
\hline She & was & still sort of crying \\
\hline Carrier & Process: Relational/Attributive & Attribute \\
\hline
\end{tabular}

(15b)

\begin{tabular}{|l|l|l|}
\hline She & was crying & a bit \\
\hline Behaver & Process: Behavioral & Circumstance: Manner \\
\hline
\end{tabular}

Relational clause (15a) includes a "Carrier" expressed by a pronoun 'She' and an 'Attribute' expressed by a nominal group "sort of crying'. In contrast, Behavioral clause (15b) has only one participant and its behavioral process in which "She" is not labeled as 'Carrier" but 'Behaver' and 'crying' play their function as a process. It is questionable what causes the inconsistency in analyzing and categorizing are many ambiguous clauses that lie on the border line of Material and Behavioral. This issue will be discussed in the next section.

\section{Material or behavioral clauses}

Let us consider the following example pairs (16a) I gave him this very cold stare. [8] (16b) I stared at him coldly.

(17a) He gave me a stare of newlyawakened surprise.

[2]

(17b) He stared at me surprisingly. 
Here at syntactic ground, the grammar in (16a) is completely different from (16b) particularly the choices of process realized in each sentence but at the semantic level, sentence (16a) is synonymous with (16b). It is clear that the semantics of the verb "gave" is not the problem and it commonly subsumes material processes. The difficulty here is due to the combination of the participant. Conceptually, semantic space of "gave" covers material processes (i.e. I gave him my notebook) but at the level of semantics of clause we have to determine whether (16a) and (17a) are material or behavioral processes. In these cases, with the view of semantics of clause, considering clauses as making and exchanging messages, it is suggested that (16a) and (17a) be Behavioral processes.

Traditionally, transitivity is a concept that is associated with the verb. Halliday (1994) does base his view of transitivity on verbs but he extends it beyond to include the participants. In developing his theory of Functional grammar, Halliday (1994) broadened the traditional notion of transitivity to shift the focus away from entirely being marked on the verb. For Halliday (1994), transitivity is instead a notion to be applied to the whole clause and I do agree with him about this point. Once again whenever troubleshooting arises due to the various identification of one process type, the analyst is forced to make a decision to favor either the formal grammatical or semantic interpretation; for example,

(18) Then a slow, sly grin came over his face.

(19) A strange sort of grin went over Gerald's face, over the horror.

(20) A quivering little shudder, re-echoing from her sobbing, went down her limbs. [4]

(21) She got into bed and lay shuddering with cold.
Halliday (1994) notes that verbs such as "go" and "go over" might be classed as Material processes and "A grin" or "A quivering little shudder" are both labeled as Actor. Material processes construe figures of "doing and happening". They express the notion that some entity "does" something. So we try to ask about such processes in this way: what did a grin do? Or what did a quivering little shudder do? The answers seem nonsense. For this reason, they are not Material. In our structural -functional approach view, these above examples are prototypical behavioral clauses.

Likewise, some Vietnamese clauses are either material or behavioral in terms of grammatical or semantic categories. For example,

(22) Chị Tiên nở một nụ cười trên mô $i$ thắm.

Ms. Tien bloom a smile on lips vermilion.

'Ms. Tien smiles a smile on her vermilion lips.'

(23) Chúng tôi nhắm mắt, nhắm mũi lại lăn ra cưòii. [13] We close eyes close nose again roll out laugh

'we laugh out loud'

Actually, the verb "nơ" itself is the common verb in material process, but in the expression "nơ nu cuori $i$ ", it contains the meaning of behavior "smile" and it should be analyzed as a behavioral process. Here are some more examples.

(24) Cặp vợ chồng Văn Minh đưa mắt nhìn nhau rất chán nản. [14] The couple Van Minh give eyes look each other very depressing

'Van Minh couple looks at each other depressingly'

(25) Văn Minh đưa mắt nhìn Xuân Tóc Đỏ.

Toc Do

Van Minh give eyes look Xuan

'Van Minh looks at Xuan Toc Do' 
Below is an example of process "smile" which is nominalized and labeled as a behavior in Vietnamese.

(26) Nu cười đong đưa, tung tẩy trên khóe mắt.

corner eyes

Smile swing toss freely on

'An attractive smile comes over the corner of her eyes'

At process level, this is understandable that the verb "đong đưa" is a prototypical one for material processes and we interpret (26) as a material clause. There is however one potential problem in this example which needs to be addressed, that is, "Nu curờ" (smile) is nominalized and labeled as an actor while "Nu cuoòi" is non-human doer. It cannot do this kind of action "dong dua". When we take the priority of semantic clause it should be treated as behavioral clause.

Consider the following example

(27) Xuân rơm rớm nước mắt [14]

Xuan moist-REDUP tears

'Xuan's eyes are moist with tears'

"Rơm rớm" is a case of reduplication (REDUP) of "róm" in Vietnamese. It is quite reasonable to describe "rơm rớm" in (27) as a "doing-word" since it means fluid discharges or leak slowly. It subsumes material processes at its process level. But we cannot focus exclusively on the meaning of verb itself and leave out meaning of the whole structure of the clause where it appears. In this case "rơm rớm nước mắt" (moist with tears) should be analyzed as Behavioral at the semantic level of the clause.

Indeed, as discussed above. Whenever there is indeterminacy in analyzing and classifying Behavioral clauses due to the conflict of semantic of process and clause, we do give priority to semantic clause and put it in the central place in this study.

\subsubsection{Clauses with two processes}

Processes are the core of the clause from the experiential perspective. The process is typically realized by a verb group in the clause. Generally, there is only one lexical verb in a simple clause but in many cases, more than one lexical verb can be found in a simple clause in our selected data as in:

(28) All of a sudden I started to cry.

(29) She began to cry again.

"Started to cry" and "began to cry" in the above examples contain two separate lexical verbs. And there is often an argument about the choice of these two verbs to classify which category the clauses seem to fall into. To shoot this trouble, we follow Halliday (1994) and Martin et al. (1997), seeing these verbal group complexes as single process and treating "the second verbal group as the relevant one for process type". Therefore, "started to cry" and "began to cry" are Behavioral processes.

In Vietnamese, some similar cases are found in our selected data.

Chân tay bà đã bắt đầu run rẩy.

Ho bắt đầu k đến cho gia đình Hận.

Unlike the above kind of verb group, in the data of this study, we face with some clause complexes where there are two clauses and two separated processes accordingly as show in

(30) ||| He paused; // gazed at me || [1]

(31) ||| She narrowed her eyes // and shivered |||

(32) ||| She lifted her head // and sighed |l|

Before we analyze further, here's a little intrusion on the analytical convention to be used for clause complexes. It is essential that clause complexes be indicated differently from ranking clauses. Ranking clauses are marked off by $\|\ldots\|$. A clause complex, on the other hand, is marked off this way: ||...|||. We will use this convention 
throughout this study. How do we analyze and classify these clauses. According to Martin et al. (1997), these clauses should be treated as clause complexes in which one participant is omitted. In the words, the elliptical participant is unavailable as analyzed below. nature of participants will thus vary according to the process type. The others two "Behavers" are omitted. In this case our suggested interpretation is that (33) should be treated as clause complexes with three processes.

(32) || Các chị phải núp khuôn mặt hình trái xoan dưới nhánh cỏ, //chỉ dám đưa mắt

\begin{tabular}{|c|c|c|c|}
\hline $\mathrm{He}$ & paused; & gazed & at me \\
\hline Actor & Process: Material & Process: Behavioral & Circumstance \\
\hline
\end{tabular}

\begin{tabular}{|c|c|c|c|}
\hline She & narrowed & her eyes & and shivered \\
\hline Actor & Process: Material & Goal & Process: Behavioral \\
\hline
\end{tabular}

\begin{tabular}{|c|c|c|c|}
\hline She & lifted & her head & and sighed \\
\hline Actor & Process: Material & Goal & Process: Behavioral \\
\hline
\end{tabular}

There is an ellipsis of the "Behaver" in the above examples. These three examples are cases of clause complexes with the absence of the participants. They include two processes: Material and Behavioral. This view is also supported by Martin et al. (1997).

Every clause of Vietnamese includes the "does what" elements. These are realized by verbal groups representing different types of processes: doings, happenings, feelings, behavings and beings. For example,

(33) ||| Điệp và Xuân lại giật mình// nhìn nhau và // dò xem//Lan muốn gì. ||| [11]

Diep and Xuan again startle look each other and observLan want what

'Diep and Xuan startled again, looked at each other and tried to find out what Lan wants.'

(34) || Cứ mỗi khi Lan cụa, /hoặc rên ||

Whenever Lan stir or sigh.

'Whenever Lan stirred or sighed'

In example (33) there are three lexical verb groups "giật minh" (startle) "nhìn" (look at) and "dò xem" (find out) labeled as Behavioral processes but there is only one "Behaver" "Điệp và Xuân”. Most typically a process goes with its own type of participant and the lên nhìn trộm ||

Sisters have to hide face oval under branch grass only dare give eyes up peep

'They have to hide their oval faces under grass, only dare to peep'

(33) |||cô e lệ //nép vào bên //nhường lối cho tôi //hay nơ một nu cuời trên đôi môi thắm||

She shy nestle cede way for me or bloom a smile over lips vermilion

'She is shy and nestles to make way for me or smiles a smile on her vermilion lips.'

We did not assess whether our group was made of consistently semantic interpreters and syntactic interpreters; however, this result does support a split between the two approaches to clausal analysis

3.2.2.3. Clause complexing and circumstantial transitivity in behavioral clauses

The last case of difficulty to be considered is the patterns of agnation between circumstance types in clause and the logico-semantic types of relation in the clause complex. Halliday (1994) states that "the patterns of agnation involving the process type typically involve grammatical metaphor". For example, the Circumstance of Means in the clause:

(34a) He looks at me with a smile. 
(34a) is agnate with an elliptical clause link to she looks at me in a clause complex:

(34b) ||| He looks //and smiles at me. ||

The phrase "with a smile" is labeled as Circumstance with the domain of a clause whilst the elliptical clause "smiles at me" expands the clause, building up a clause complex. At semantic clause level they are synonymous but they are distinctive in terms of syntactical layer. The circumstantial prepositional phrase "with a smile" and the elliptical clause "smiles at me" are fairly synonymous but only the latter has the grammatical potential of a clause to open up a clause complex. In this study, we consider (34b) as a clause complex with Behavioral process "smiles" and an elliptical Behaver. There are many examples of circumstances serving within the domain of the clause with suggested agnate clauses within the domain of the clause complex.

(35) He looked round, half furtively, with a sort of cunning grin.

(36) His mouth opened with a strange, ecstatic grin.

Let's compare these above examples with this clause "she cuts this tree with an axe". Here "with an axe" is labeled as Circumstance of
Manner-Means. But is this a case of "with a sort of cunning grin" in (35)? Halliday (1994) states that there are five sources of difficulty in identifying circumstance elements, that is, (i) prepositional phrase as participant; (ii) preposition attached to verb; (iii) preposition phrase (as Qualifier) inside nominal group; (iv) preposition phrase as Modal or Conjunctive Adjunct and (v) abstract and metaphorical expressions of circumstance. "With a sort of cunning grin" is a case of (i) causing indeterminacy in analyzing and labeling it. In this study, our suggestion is that these examples be treated as clause complexes with two processes.

In comparison with Vietnamese, there are no cases of agnation in our collected data since no prepositional phrases functioned as Circumstance with the domain of simple clause are found.

\subsection{Interpretation of similarities and} differences in terms of the sources of troubles in English and Vietnamese

The analysis of collected data revealed some similarities and distinctive differences between English and Vietnamese behavioral clauses as illustrated in Table 1.

Table 1. Similarities and differences in terms of the sources of troubleshooting in English and Vietnamese

\begin{tabular}{|c|c|c|c|c|c|}
\hline & \multirow{2}{*}{\multicolumn{2}{|c|}{\begin{tabular}{l|l} 
Enolish & Viotnamose
\end{tabular}}} \\
\hline & & & & & \\
\hline \multicolumn{2}{|l|}{$\begin{array}{c}\text { Unambiguous } \\
\text { cases }\end{array}$} & \multicolumn{2}{|c|}{ Behavioral processes } & + & + \\
\hline \multirow{8}{*}{$\begin{array}{l}\text { Ambiguous } \\
\text { cases }\end{array}$} & \multirow{3}{*}{$\begin{array}{l}\text { At process } \\
\text { (verb) Level }\end{array}$} & \multicolumn{2}{|c|}{ Material-behavioral processes } & + & + \\
\hline & & \multicolumn{2}{|c|}{ Verbal- behavioral processes } & + & + \\
\hline & & \multicolumn{2}{|c|}{ Mental-behavioral processes } & + & + \\
\hline & \multirow{5}{*}{ At clause level } & \multirow{2}{*}{$\begin{array}{c}\text { Clauses "Dumb" } \\
\text { process }\end{array}$} & Relational or Behavioral & + & - \\
\hline & & & Material or Behavioral & + & + \\
\hline & & \multirow{2}{*}{$\begin{array}{c}\text { Clauses with two } \\
\text { processes }\end{array}$} & Verbal group complexes & + & + \\
\hline & & & Clause complexes & + & + \\
\hline & & \multicolumn{2}{|c|}{ Clauses with circumstantial transitivity } & + & - \\
\hline
\end{tabular}


Behavioral clauses with behavioral processes are clearly recognized and interpreted in English and Vietnamese. In addition, through our contrastive analysis of the sources of troubleshooting in classifying and labeling behavioral clauses in English and Vietnamese, at clause level both languages share the same common features. On the borderline between processes, Material-behavioral, Verbalbehavioral Mental-behavioral processes are found in both English and Vietnamese.

However, at clause level, there are some common and distinctive features in English and Vietnamese. Firstly, the problem arises at this level when the type of process and clause conflicts. To settle this conflict, we are in favor of semantic treatment. In other words, as the conflict between the process type and clause type occurs, we suggest making a decision to favor semantic clause interpretation. This helps analysts have firm framework and evidence to determine the clause type and function. In this study, we have trouble interpreting Relational or Behavioral and Material or Behavioral in English. But Relational or Behavioral clause confusion is not available in Vietnamese. Secondly, clauses with one participant and more than one lexical verb are found in English and Vietnamese. At sub-type level, verbal group complexes and clause complexes are present in both English and Vietnamese. Finally, clauses with circumstantial transitivity occur most frequently in the English data but it are not found in the Vietnamese data. It can be inferred from this that Vietnamese writers tend to use clause complexes rather than prepositional phrases functioning as Circumstance with the domain of simple clause.

\section{Conclusion}

We aim at investigating shooting the troubles in analyzing and classifying behavioral clauses. In doing so, we provide explanation of sources of indeterminacy to address the problem in the light of structural-functional approach. In analysing 200 behavioural clauses from 16 English and Vietnamese novels and short stories, we find out the two situations that appear to contribute to the problem of analysis and category. First, at process level, interpreting behavioral clauses with behavioral processes does not present any problem in analyzing and labeling unambiguous behavioral clauses. However, interpreting verbs fitting more than one category of a process and on the borderline between processes is very challenging. The three subtypes of behavioral processes, namely Material-behavioral, Verbalbehavioral and Mental-behavioral processes are found. Second, our main discussion is about the situations where the semantic and syntactic interpretation of the behavioral clauses is inconflict and the options are split on which two processes should be selected. This case is overwhelmingly driven by ambiguity of "dumb" process especially between material and behavioral clauses both in English and Vietnamese. In this study, when the semantic and syntactic conflict occurs, we tend to take semantic as priority of semantic since we are under the light of functional grammar regarding language as "a resource for making meaning" and as a vehicle for communication between people in social and cultural contexts. Finally, a contrastive analysis of the sources of troubles for shooting, classifying and labeling behavioral clauses in English and Vietnamese is carried out. These findings suggest that when we analyze and classify the clauses, we should not focus on the process itself as an island of information, but rather put it on the broader scale - the clause.

\section{References}

Bloor, T. \& M. Bloor (1995). The Functional Analysis of English: A Hallidayan Approach. Edward Arnold..

Eggins, S. (1994). An introduction to Systemic Functional Linguistics. London and New York: Continuum..

Fawcett, R. (2010). A Theory of Syntax for Systemic Functional Linguistics. Amsterdam: John Benjamins.

Gwilliams, L. \& L. Fontaine (2015). "Indeterminacy in process type classification". Functional Linguistics; 2:8. London: Springer.

Halliday, M.A.K. \& C.M.I.M. Matthiessen (2004). An introduction to Functional Grammar. $3^{\text {rd }}$ ed. London, Arnold. 2004. Halliday \& Matthiessen.

Halliday, M.A.K. (1004). An Introduction to Functional Grammar. Arnold, London.

Hoang Van Van (2012). An Experiential Grammar of the Vietnamese Clause. Ha Noi: Viet Nam Education Publishing House. 
Martin, J. R., C.M.I.M. Matthiessen and C. Painter (1997). Working with Functional Grammar. London: Edward Arnold.

O’Donnell, M., M. Zappavigna \& C. Whitelaw (2009). “A survey of process type classification over difficult cases. (In) Language to Multimodality: New Developments in the Study of Ideational Meaning. Jones, C. and E. Ventola (eds.), 47-64. London: Continuum.

Thompson, G. (1996). Introducing Functional Grammar. London: Arnold.

Webster, J. (2014). Understanding Verbal Art: A Functional Linguistic Approach. London: Springer.

\section{Data sources}

\section{English}

[1] Bronte, C. Jane Eyre. Smith, Elder \& Co. of London, England. 1847.

[2] Bronte, E. Wuthering Heights. Harper \& Brothers, Publisher. New York. 1858.

[3] Fitzgerald, F. S. The Great Gatsby. Scribner, New York. 1925.

[4] Lawrence, D.H. The Rainbow. Collector's Library, China. 2004.
[5] Lawrence, D.H. Women in love. Dover publications, Inc. New York. 1920.

[6] Lawrence, D.H. Sons and Lovers. Dover publications, Inc. New York. 1919

[7] Sailing, J.D. The Catcher in the Rye. An imprint of Infobase Publishing. New York. 1951.

\section{Vietnamese}

[8] Nam Cao. Sống mòn. Nhà xuất bản Văn học.Việt Nam.1956.

[9] Nam Cao. Chí Phèo. Nhà xuất bản Văn học.Việt Nam.1957.

[10] Nguyễn Ngọc Tư. Cánh đồng bất tận. Nhà xuất bản Trẻ.Việt Nam.2011.

[11] Nguyễn Công Hoan. Tắt lưa lòng. Nhà xuất bản Văn học. Việt Nam. 2004

[12] Thạch Lam. Tuyển tập Thạch Lam. Nhà xuất bản Trí Việt. Việt Nam. 2012

[13] Tô Hoài. Dế mèn phiêu luu ký.Nhà xuất bản Kim Đồng. Việt Nam. 2007

[14] Vũ Trọng Phụng. Tuyển tập Vũ Trong Phung Tập 1.. Nhà xuất bản Văn học. Việt Nam. 2016

[15] http://www.5book.vn/chapter/truyen-ngan-namcao/QEdL

\title{
MỘT SỐ GIẢI PHÁP CHO VIẸC XÁC ĐỊNH VÀ PHÂN LOẠI CÁC QUÁ TRİ̀H HÀNH VI TRONG TIẾNG ANH VÀ TIẾNG VIẸT
}

\author{
Nguyễn Thị Tú Trinh ${ }^{1 *}$, Phan Văn Hòa ${ }^{2}$, Trần Hữu Phúc \\ ${ }^{1}$ Khoa tiếng Anh, Truờng Cao đẳng Giao thông vận tải II, \\ 28 Ngô Xuân Thu, Liên Chiểu, Đà Nã̃ng, Việt Nam
}

${ }^{2}$ Khoa Đào tạo quốc tế, Đại học Đà Nã̃ng, 41 Lê Duẩn, Quận Hải Châu, Đà Nã̃ng, Việt Nam

${ }^{3}$ Truoòng Đại học Ngoại ngũ, Đại học Đà Nã̃ng,

131 Luơng Nhũ Hộc, Phương Khuê Trung, Quận Cẩm Lệ, Đà Nã̃ng, Việt Nam

Tóm tắt: Không giống các quá trình vật chất có các đặc điểm khu biệt ở cả hai bình diện ngữ nghĩa là ngữ pháp - từ vựng, các quá trình hành vi không có các đặc điểm đặc trưng như một phạm trù ngữ pháp khu biệt. Do sự mơ hồ về ngữ nghĩa nên chúng thường gây ra rất nhiều khó khăn cho việc xác định và phân loại. Đã có nhiều cố gắng nhằm làm sáng tỏ vấn đề này trong cả tiếng Anh và tiếng Việt (ví dụ, Halliday, 1994; Halliday \& Matthiessen, 2004; Eggins, 1994, Martin và cộng sự, 1997; Hoàng Văn Văn, 2012), nhưng vẫn còn tồn tại một số vấn đề cần phải làm rõ hơn. Trong bài báo này, chúng tôi sẽ cố gắng nghiên cứu sâu các nguyên nhân của những khó khăn này và sẽ đề xuất một số gợi ý để xử lí những khó khăn đó. Dữ liệu nghiên cứu là 200 cú hành vi trong tiếng Anh và tiếng Việt được thu thập từ các truyện ngắn và tiểu thuyết. Trên cơ sở khung lí thuyết ngữ pháp chức năng của Halliday (1994), nghiên cứu cho thấy rằng để có thể xác định và phân loại một cách thoả đáng một quá trình (động từ) hành vi, cần thiết phải đặt nó trong mối quan hệ với các thành phần khác trong cú và cả hai tiêu chí ngữ nghĩa (ý nghĩa) và ngữ pháp - từ vựng (cấu trúc) đều phải được xem xét.

Tù khóa: ngữ pháp chức năng, chức năng ngữ pháp, cú hành vi 